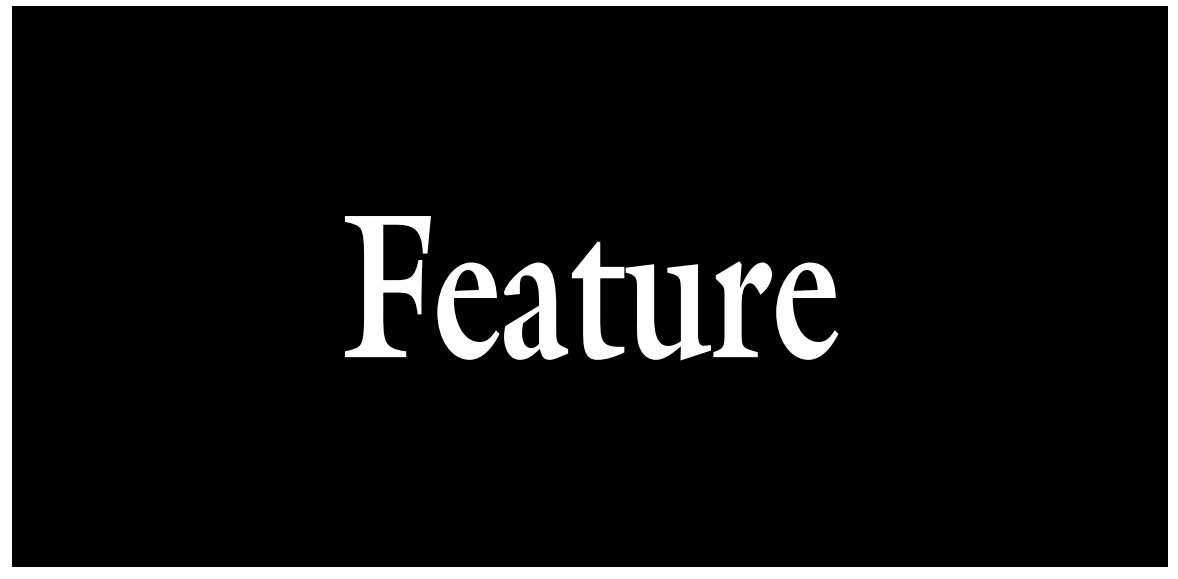

\section{Development and Commercialization of a Complete Vineyard Mechanization System}

\author{
Justin R. Morris ${ }^{1,2}$
}

AdDitional INDEX wORDs. balanced cropping, shoot thinning, fruit thinning, crop load, pruning, wine quality, economics

SUMmARY. A major research thrust of the University of Arkansas Enology and Viticulture Program for the past 37 years has been the development of a total vineyard mechanization system. This new system allows the mechanization of almost all practices in vineyard operations, including dormant and summer pruning, leaf removal, shoot and fruit thinning, canopy management, and harvesting while fruit quality is maintained or enhanced. Research efforts aimed to accomplish these tasks on the $\mathbf{1 2}$ major trellising systems used throughout the industry and to derive plans for the sequencing and timing of operations on each of the trellis systems. In 2002, the University of Arkansas patented the Morris-Oldridge Vineyard Mechanization System (M-O System). OXBO International Corp., Clear Lake, WI, purchased the patent and market M-O System components under the name Korvan ${ }^{T M}$ Vineyard System. The objective of this study was to evaluate the effectiveness of mechanized (machine-farmed) pruning, shoot thinning, and fruit thinning using the M-O System vs. traditional methods of canopy management using hand labor (hand-farmed) in a commercial Vitis vinifera vineyard in the central coast region of California. $V$. vinifera cultivars evaluated included Chardonnay, Sauvignon blanc, and Syrah trellised on a lyre system and Merlot, Zinfandel, and Sangiovese trellised on a vertical shootpositioned (VSP) system. Yield, fruit growth, fruit composition, wine quality, wine sensory attributes, and economics of mechanization were evaluated on machineand hand-farmed grapes. Mechanized studies were initiated at French Camp Vineyards, Santa Margarita, CA, in 2002. French Camp Vineyards used a balanced cropping concept which incorporated three operations: 1) machine dormant pruning, 2) machine shoot thinning, and 3) machine fruit thinning. Results of research from 2002 to 2005 showed that yield and quality characteristics of machine-farmed grapes were not statistically different from those of hand-farmed grapes for the $V$. vinifera cultivars in this study. Wines from each cultivar and treatment were produced at a commercial winery and after appropriate aging, were sensory-evaluated by a professional wine analysis service. Few sensory differences were found between wines from the two farming systems. Further objective analyses of the wine components showed no commercially practical differences. In 2006, cost estimates were derived for the three vineyard activities necessary to achieve balanced cropping. Use of machine farming for balanced cropping operations resulted in savings over hand farming of $45 \%$ on the lyre trellis, $49 \%$ on the VSP system, and $62 \%$ on the quadrilateral trellis for the operations studied. Studies of mechanization of vineyard activities using the M-O System to achieve balanced cropping have shown that grapes and their wines were equivalent to those obtained using hand labor for these operations with the added benefit of cost savings for the operations evaluated.
T Traditionally, growers of premium wine grape cultivars have used hand labor in vineyards. The scarcity and increased cost of hand labor and the increased competition from global markets with inexpensive labor have caused commercial growers to depend on mechanization in the vineyard to ensure market competition. Research has been conducted by the Enology and Viticulture Program, University of Arkansas, Fayetteville, since 1966 on postharvest handling, adapting harvesters to different trellises, and adapting, developing, and evaluating machines that mechanize canopy management practices in vineyard operations such as dormant and summer pruning, leaf removal, shoot positioning and shoot and fruit thinning. The goal was to develop systems that would allow complete mechanization of mature commercial vineyards without loss in fruit quality (Morris, 1979, 1985, 1986; Morris and Cawthon, 1979, 1980a, 1980b, 1980c, 1981a, 1981b; Morris et al., 1984a, 1984b).

Vineyard MechanizationHistory. The earliest research on vineyard mechanization was a study involving harvesting at the University of California (UC), Davis, in the early 1950s (Winkler et al., 1957). Researchers developed trellises that positioned the grapes to hang under the wire. A cutter-bar machine was mounted on a tractor to harvest the grapes by severing the clusters, allowing them to drop onto a conveyor belt. This approach was never commercialized because the cutter bar cut through too many clusters, and eventually this research was abandoned.

In 1957, a team of scientists at Cornell University's Experiment Station, Geneva, NY, took an entirely different approach. A specialized double-curtain trellis, which became known as the Geneva double curtain (GDC), was developed for growing Concord grapes (Vitis labrusca) (Shaulis et al., 1960). A mechanical harvester that literally shook the grapes off the vines a half a row (one of the two curtains) at a time was also developed, and the Chisholm Ryder Co. (Niagara Falls, NY) began commercial production of this machine.

In the early 1960s, two Concord grape growers, R. Orton and $M$. Orton from Ripley, NY, adapted a 
cane fruit harvester designed by B. Weygandt to harvest grapes. Large plywood panels were mounted on the harvester so that they struck each side of a cordon row. This machine was the prototype of the $\mathrm{O}-\mathrm{W}$ harvester (Chisholm Ryder Co.) (Shepardson et al., 1969), which became the model for all other machines using this shaking action (May, 1995; Morris, 2006).

By the late $1960 \mathrm{~s}$, commercial adoption of mechanical harvesters for both juice and wine grape vineyards was becoming common. In the late 1960 s and early 1970s, the postharvest quality of mechanically harvested Concord grapes was studied (Morris et al., 1979). Alcohol and soluble solids measured from harvest bins at 6-h intervals showed that mechanically harvested Concord grapes had a rapid increase in fermentation rates with time, emphasizing that the time between mechanical harvesting and processing of grapes significantly affects product quality as determined by alcohol production and loss of soluble solids. Industry used this information to establish a maximum 6-h interval between mechanical harvesting and processing. In addition, as shown in Fig. 1, fruit temperature in bulk pallets did not change significantly with holding time, but higher fruit temperatures increased the rate of grape deterioration. As a result, to improve the commercial quality of machineharvested grapes, a recommendation to harvest at night when fruit temperatures were cooler was made.

Improvements in harvesting machines over the years included at least nine major modifications: 1) beating elements evolved from large This paper was partially presented as an invited paper
to the Mechanization Working Group at the ASHS
Annual Conference, New Orleans, LA, 27-30 July 2006.

Published with the approval of the Director, Arkansas Agricultural Experiment Station

This research was a cooperative effort with French Camp Vineyards (Santa Margarita, CA) and OXBO International Corp. (Clear Lake, WI). The author acknowledges the scholarship and dedication of over 30 graduate students during the past 37 years and current postdoctoral associates, Drs. Gary Main and Renee Threlfall, who have worked on the myriad aspects of vineyard mechanization. Thanks are also given to Drs. Pamela Brady and Janice Blevins for their assistance in preparing the manuscript, Greg Berg, OXBO viticulturalist, and Hank Ashby, French Camp Vineyards Manager, for their invaluable assistance during this evaluation.

${ }^{1}$ University of Arkansas, Division of Agriculture, Institute of Food Science and Engineering, 2650 North Young Avenue, Fayetteville, AR 72704

${ }^{2}$ Corresponding author. E-mail: jumorris@uark.edu. flat panels to fiberglass rods; 2) rods were upgraded to more flexible bow rod units; 3) narrower machines became available to accommodate row widths of $4.25 \mathrm{ft}$; 4) four-wheel drive permitted better traction on difficult terrain; 5) hydraulic transmission provided variable speed; 6) self-leveling devices permitted machines to operate on slopes; 7) pendulant units on frames, with automatic adjustments, followed the alignment of the vine canopy; 8) on a few machines, attachments were added for auxiliary uses such as crushing, destemming, and sulfiting the must; and 9) chassis attachments were made available to allow multipurpose uses, such as spraying, cultivating, pruning, etc. (Morris, 2000).

Once the harvesting operation was mechanized, the pruning and tying operations became the most time-consuming hand-labor operations in the vineyard. The development and adoption of trellises that could be totally mechanized became of paramount importance. Trellises were needed that would allow maximum accessibility of the fruit to the harvester's shaking mechanism and effective mechanical pruning for each vine growth habit. Properly trained vines had to accommodate efficient machine operations without excessive damage to the vines or reductions in yield or quality (Morris, 2000; Morris and Cawthon, 1979).

The M-O System. The author and $\mathrm{T}$. Oldridge, a grape grower and inventor, developed the M-O System, which includes over 40 different machines and attachments ( 20 of the machines or attachments used in the M-O System already existed in industry) that have been designed for the mechanization of the 12 major trellis configurations used throughout the world. During the years of research and development, the M-O System was foremost monitored for its ability to efficiently mechanize vineyard activities while maintaining fruit quality. When these objectives were not met, the researchers simply went back to the drawing board. As a result, the U.S. patent for "Vineyard apparatus, system, and method for vineyard mechanization" (Morris and Oldridge, 2002) was issued to the University of Arkansas in Apr. 2002. OXBO International Corp. (Clear Lake, WI) acquired the license to the M-O System and began manufacturing and marketing the system as the Korvan ${ }^{\mathrm{TM}}$ Vineyard System.

A unique aspect of the $\mathrm{M}-\mathrm{O}$ System is that, until its development, there had been no commercial system developed for the major trellis configurations that detailed the appropriate machine to use at the proper time for each operation. Details and timetables for the mechanization of both upright and drooping growth habit grape cultivars are included in the system designs. Sequences of steps and timing of operations for two of

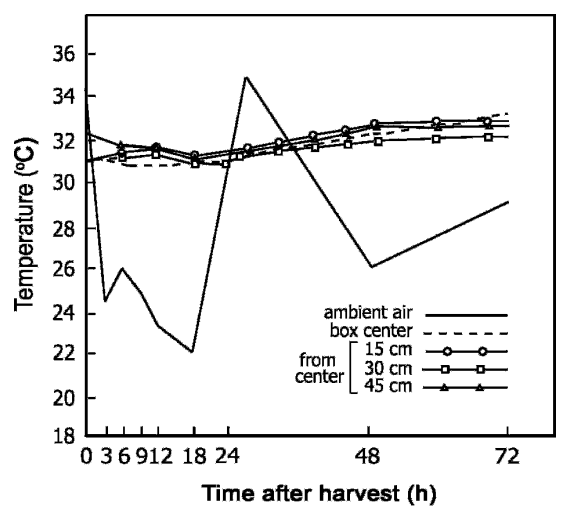

Fig. 1. Ambient air temperature and grape temperatures at various locations in a bulk pallet box after harvest; $\left(1.8 \times{ }^{\circ} \mathrm{C}\right)+32={ }^{\circ} \mathrm{F}, 1 \mathrm{~cm}=$ 0.3937 inch (Morris et al., 1979).

\begin{tabular}{llll}
\hline $\begin{array}{l}\text { Units } \\
\begin{array}{l}\text { To convert U.S. to SI, } \\
\text { multiply by }\end{array}\end{array}$ & U.S. unit & SI unit & $\begin{array}{l}\text { To convert SI to U.S., } \\
\text { multiply by }\end{array}$ \\
\hline 0.4047 & $\mathrm{acre}(\mathrm{s})$ & $\mathrm{ha}$ & 2.4711 \\
29.5735 & $\mathrm{fl} \mathrm{oz}$ & $\mathrm{mL}$ & 0.0338 \\
0.3048 & $\mathrm{ft}$ & $\mathrm{m}$ & 3.2808 \\
2.54 & inch $(\mathrm{es})$ & $\mathrm{cm}$ & 0.3937 \\
0.4536 & $\mathrm{lb}$ & $\mathrm{kg}$ & 2.2046 \\
1.4882 & $\mathrm{lb} / \mathrm{ft}$ & $\mathrm{kg} \cdot \mathrm{m}^{-1}$ & 0.6720 \\
28.3495 & $\mathrm{oz}$ & $\mathrm{g}$ & 0.0353 \\
0.001 & $\mathrm{ppm}$ & $\mathrm{g} \cdot \mathrm{L}^{-1}$ & 1000 \\
2.2417 & $\mathrm{ton} / \mathrm{acre}$ & $\mathrm{t} \cdot \mathrm{ha}^{-1}$ & 0.4461 \\
$\left({ }^{\circ} \mathrm{F}-32\right) \div 1.8$ & ${ }^{\circ} \mathrm{F}$ & ${ }^{\circ} \mathrm{C}$ & $\left(1.8 \times{ }^{\circ} \mathrm{C}\right)+32$ \\
& & &
\end{tabular}


these training systems, GDC-type trellises used with grapes with a drooping growth habit and the lyre or "U" trellis are shown in Figs. 2 and 3 , respectively.

A key component to the efficient use of the M-O System is implementation of the concept of "balanced cropping." Before the introduction of mechanization systems, balanced dormant hand pruning based on records of past yields and vine vigor had traditionally been used to control crop level. But this operation was done before hard spring freezes, hail storms, poor fruit set, and other acts of natural crop reduction and therefore could result in low yields.

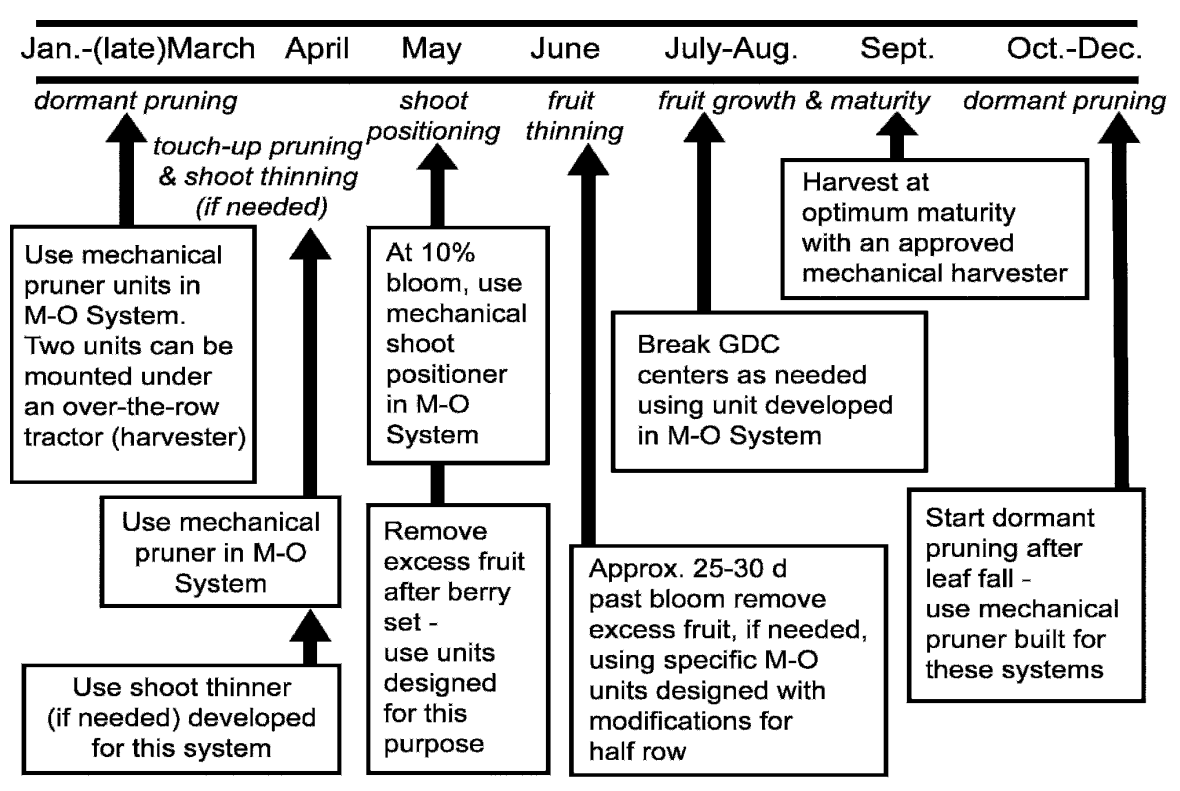

Fig. 2. Steps and timing of operations in the Morris-Oldridge Vineyard Mechanization System (M-O System) for Vitis labruscana on Geneva double-curtain (GDC) or GDC-like trellises. (Designed for viticultural regions in the United States. Appropriate timing would be modified for the southern hemisphere and other viticultural regions).

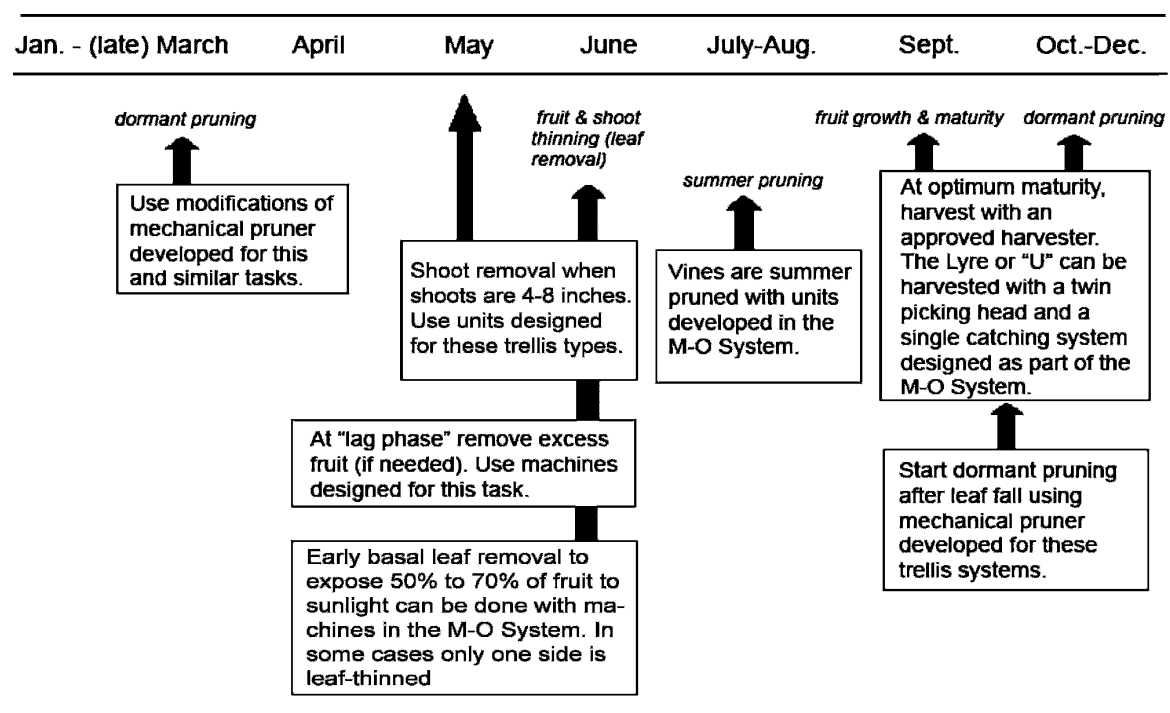

Fig. 3. Steps and timing of operations in Morris-Oldridge Vineyard Mechanization System (M-O System) for Vitis vinifera on lyre or "U" trellises; 1 inch $=2.54 \mathrm{~cm}$. (Designed for viticultural regions in the United States. Appropriate timing would be modified for the southern hemisphere and other viticultural regions).
Because mechanized thinning can be accomplished rapidly, a larger potential crop (more nodes) can be left after pruning as a buffer against nature's own crop reduction activities. Then, after the risk of most natural disasters has passed, shoot thinning and, if needed later, fruit thinning, can be used to fine-tune the crop load. This balanced cropping is possible because mechanized vineyard operations are fast and make incremental adjustments for fine-tuning the crop load a reality. Although balanced cropping can be accomplished by hand, use of mechanized systems to adjust fruit load is more cost- and time-effective.

The objective of this study was to evaluate the effectiveness of mechanization using the M-O System for pruning, shoot thinning, and fruit thinning in a commercial $V$. vinifera vineyard in the central coast region of California and to compare it with traditional methods of canopy management using hand labor. Yield, fruit growth, fruit composition, wine composition, wine sensory analysis, and economics of mechanization using the M-O System were evaluated for hand- and machinefarmed grapes.

\section{Materials and methods}

VINEYARD. The commercial vineyard site used in this study was French Camp Vineyards (Santa Margarita, CA). The vineyard owners (Miller Family) and the vineyard manager (Hank Ashby) had followed the development of the M-O System and were committed to evaluating the system on high-quality grapes. The vineyard site (Region III) has a soil type of Arbuckle sandy loam with a sprinkler system for overhead frost protection and a drip irrigation system. The trellis systems used in this study in the vineyard included $2-\mathrm{ft}$ lyre and VSP. A 3 - $\mathrm{ft}$ quadrilateral (quad) trellis was added for the economic evaluation.

Cultivars. V. pinifera cultivars evaluated included Chardonnay, Sauvignon blanc, and Syrah trellised on a lyre system and Merlot, Sangiovese, and Zinfandel trellised on a VSP system.

Treatment application. Hand- or machine-farming methods to achieve balanced cropping were used to produce grapes on large research plots in a commercial 
vineyard. Standard procedures in the French Camp Vineyards for canopy management used hand labor (handfarmed) to carry out all canopymanagement and fruit-thinning operations. For machine farming, mechanization using the Korvan ${ }^{\mathrm{TM}}$ equipment developed from the $\mathrm{M}-\mathrm{O}$ System replaced hand labor for pruning and shoot and fruit thinning. The land areas of machine-farmed grapes at French Camp Vineyards were 474 acres in 2003, 899 acres in 2004, and 1021 acres in 2005. Blocks of 2.5 acres within each cultivar and farming method were established to determine yield and fruit-thinning parameters along with past vineyard records of yield and dormant pruning weights.

Machines or attachments to mechanize all vineyard operations are described in the patent for the M-O System (Morris and Oldridge, 2002). Mechanization studies at French Camp Vineyards included the three operations necessary to implement a balanced cropping concept: 1) Machine dormant pruning. Precision dormant pruning using the M-O System chassis with pruning attachments shown in Fig. 4 was carried out to retain the number of nodes necessary to achieve an estimated $200 \%$ of the final desired yield level. This left a cushion for unforeseen natural conditions without

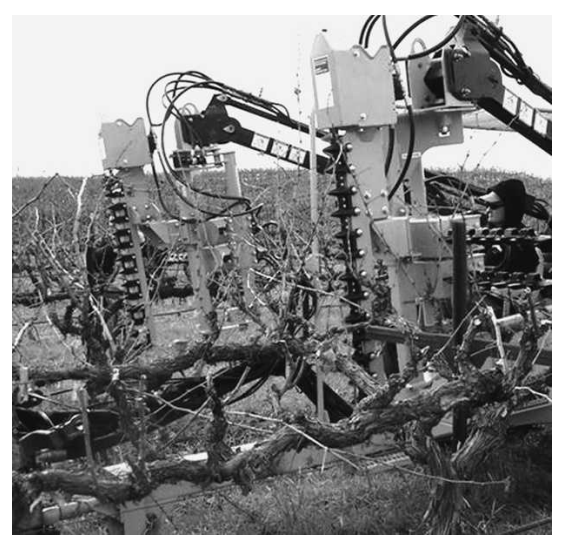

Fig. 4. Korvan ${ }^{\mathrm{TM}}$ Vineyard System chassis with shear pruning attachments on both right and left sides. This configuration allows the tractor-pulled unit to prune facing sides of adjacent rows. Shown working in Vitis vinifera at French Camp Vineyards, Santa Margarita, CA (photo courtesy of OXBO International Corp., Clear Lake, WI). reducing the crop load below the intended target. Pruning weights were recorded. 2) Machine shoot thinning. To achieve an estimated 130\% to $140 \%$ of the desired final yield level, the shoot thinner shown in Fig. 5 was used with no hand follow-up when the new shoots were $10-20 \mathrm{~cm}$. The tractor and paddle speed were adjusted so that the shoot thinner left 10-30 shoots / $\mathrm{m}$ of cordon, depending on cultivar, vine vigor, and the target yield requested by the commercial winery purchasing the grapes. Following shoot thinning, shoots per meter of cordon were counted to determine accuracy of the mechanized operation. 3) Machine fruit thinning. If the vines still exceeded the target yield after the dormant pruning and shoot thinning operations, then the fruit-thinner attachment shown in Fig. 6 was used to reach the desired crop levels during or after the berry growth "lag phase" (a period of $1-2$ weeks when there is a pause in fruit growth).

To achieve optimum rate of operation for the equipment used for each of these operations, it was necessary to adjust operating parameters, such as tractor speed, striking force, etc. to account for climatic conditions, cultivar, amount of crop to be removed, and other variables (Morris, 2004).

Cropload estimation AND FRUIT THINNING. With both hand and machine farming, estimating crop yield is an essential aspect of balanced cropping because this estimate forms the basis for determining how much fruit, if any, to remove. In addition, winery buyers often set a target yield that they feel will produce fruit with the quality characteristics needed for their wines. To adjust crop levels, crop yield estimations are key to achieving these target yields.

In the past, for hand farming, cluster weights were used in combination with cluster counts to estimate final crop load. However, this method does not work well on machinepruned vines (Pool et al., 1996). A more effective estimation method uses viticultural records of average berry weights at harvest in combination with average lag phase berry weights.

Lag phase crop level was determined by removing all the fruit from a given length of cordon (to include at least four vines). The fruit removed was weighed, and the average weight of crop per meter of cordon determined. This value was multiplied by the number of meters of cordon per

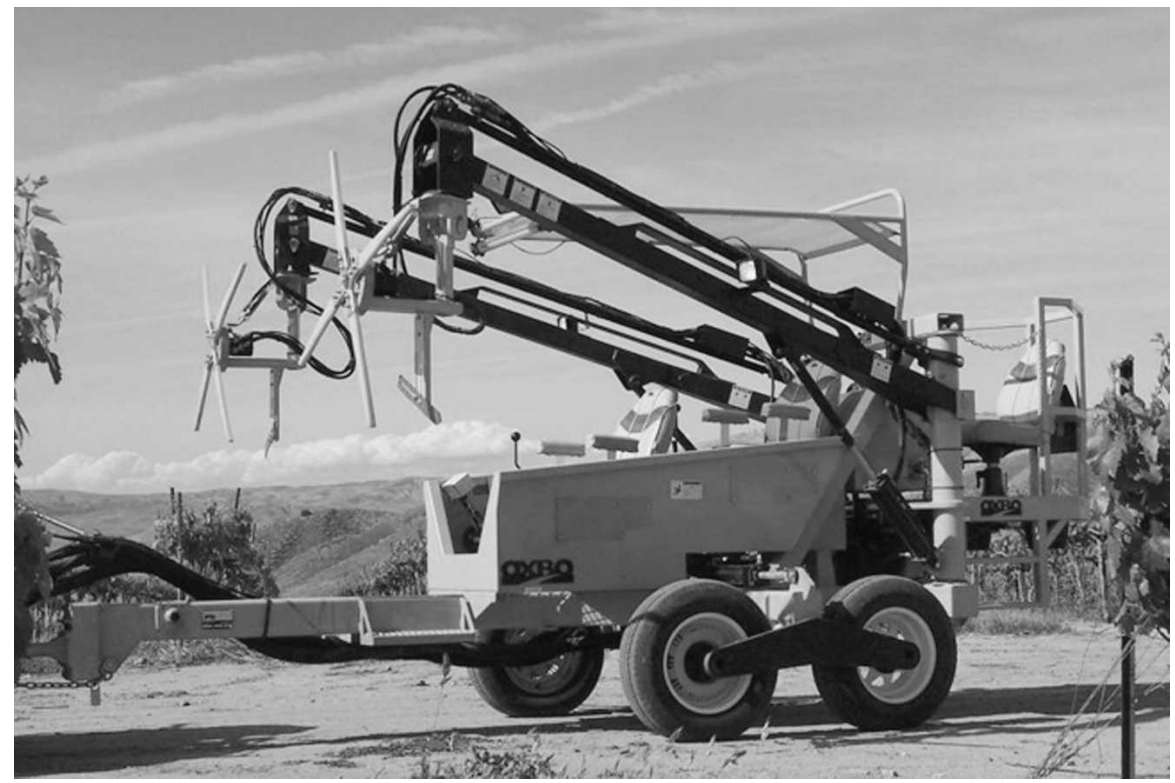

Fig. 5. Korvan ${ }^{\mathrm{TM}}$ Vineyard System chassis equipped for shoot thinning. The speed of the tractor used to pull the chassis and the speed of the thinner paddles can be adjusted so that the thinner leaves the desired number of shoots per foot of cordon, depending on cultivar and vigor (photo courtesy of OXBO International Corp., Clear Lake, WI). 
$\mathrm{ha}^{-1}$ in the plot to provide an estimate of the lag phase crop load.

Average lag phase berry weight was calculated from 200-berry samples. Because lag phase berry weight has been shown to correlate with final berry weight (Fisher et al., 1997), dividing the historical average harvest berry weight by the lag phase berry weight gave a multiplication factor which, when applied to the value obtained for lag-phase crop load, provided an estimate of final crop load. A comparison of the estimated final crop load to the target yield set by the winery buyer provided guidance in determining the amount of fruit to remove to achieve the target yield. A fruit thinner was then used to adjust the crop load to desired levels. When determining the amount of fruit to be thinned, it was also necessary to include a correction factor to account for berries and clusters damaged during thinning but left on the vine, as shown in Fig. 7.

In mechanical thinning, the thinner must be adjusted to achieve the desired level of fruit removal. To adjust the fruit thinner, fruit was removed from a given length of cordon. The fruit was weighed, and the resulting crop load calculated. If the desired crop load was not achieved, the operating speed of the fruit thinner was adjusted and the procedure repeated until the desired amount of fruit was removed.

Harvest determination. Sampling to monitor fruit maturation began at veraison, when grapes had $\approx 15 \%$ soluble solids, and continued weekly until grapes reached $20 \%$ soluble solids. Two hundred berries were randomly collected from each cultivar and farming method block every other day until the grapes reached $22 \%$ soluble solids. At this point, samples were taken every day until the desired soluble solids for each cultivar was reached. The same harvest date was used for both farming methods on a given cultivar. Yield was determined by weighing fruit from each cultivar and farming method experimental block.

Harvest samples. At harvest, 30 clusters from each cultivar and farming method were randomly selected for analysis. Clusters were weighed and the berries on each cluster counted to determine average berry weight. For juice analysis,

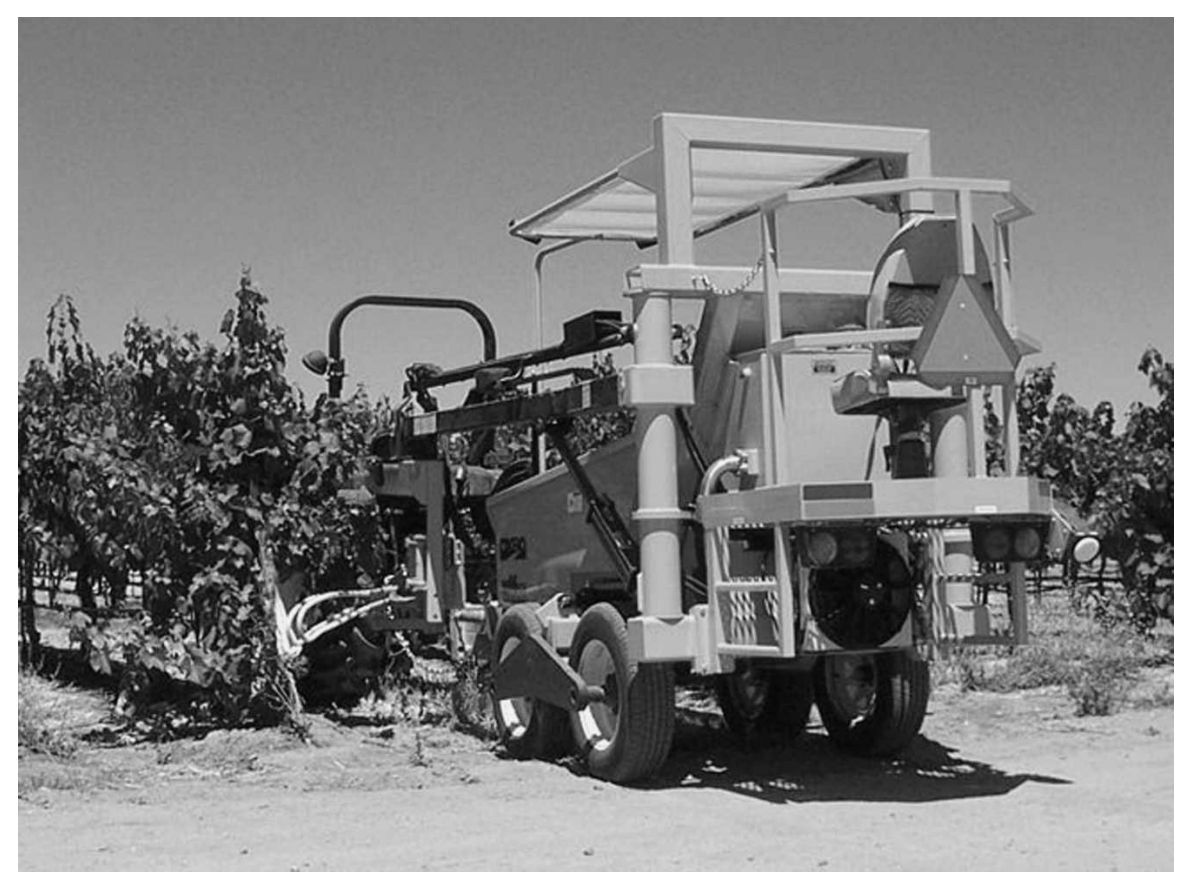

Fig. 6. Korvan ${ }^{\mathrm{TM}}$ Vineyard System chassis equipped with grape thinning attachments for bottom thumper fruit thinning on $2-\mathrm{ft}(0.6-\mathrm{m})$ lyre and quadrilateral-trained vines. Shown working in Vitis vinifera at French Camp Vineyards, Santa Margarita, CA (photo courtesy of OXBO International Corp., Clear Lake, WI).

clusters were put through a handoperated crusher with the rollers adjusted so that stems and rachises were not crushed.

Compositional anALYsis. Juice and wine $\mathrm{pH}$ were measured with a pH meter (model 250; Beckman Coulter, Fullerton, CA). Titratable acidity (tartaric acid in grams per liter) was measured by placing $5 \mathrm{~mL}$ of juice into $125 \mathrm{~mL}$ of degassed, deionized water and titrating with $0.1 \mathrm{~N}$ sodium hydroxide to an endpoint of pH 8.2 (Iland et al., 2004). Total soluble solids were measured using a Bausch and Lomb Abbe Mark II refractometer (Scientific Instrument, Keene, NH). Residual sugars (D-glucose $+\mathrm{D}$-fructose) and ethanol (percent by volume) were measured by high-performance liquid chromatography using methods described by Walker et al. (2003).

Color and phenolics of the juice were determined using a Unicam Helios Beta ultraviolet-visible spectrophotometer (ThermoSpectronic, Cambridge, England) (Iland et al., 2004; Zoecklein et al., 1995). Total red pigment color was measured at $520 \mathrm{~nm}$ using the procedure in Iland et al. (2004). In this procedure, the juice samples were diluted with $1 \mathrm{M}$ hydrochloric acid $(\mathrm{HCl})$. The low $\mathrm{pH}$

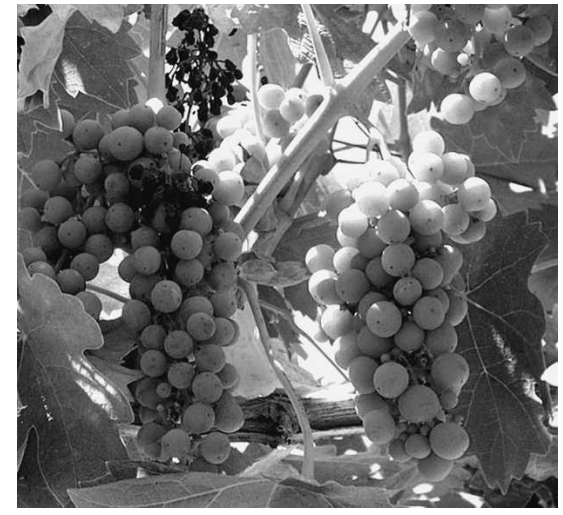

Fig. 7. Visible fruit damage present after mechanical fruit thinning in Vitis vinifera. Volume of damage must be included in the crop estimation, although the presence of the dehydrated fruit is not a problem at harvest.

of the $\mathrm{HCl}$ solution causes anthocyanins to be in the bright red-colored form (flavylium cation) and gives an estimation of the total red pigments (both anthocyanins and tannins) in the juice. Absorbance $(280 \mathrm{~nm} \times$ dilution factor - 4) of the sample diluted with $\mathrm{HCl}$ provides a measure of the phenolic material (Iland et al., 2004). Spectrophotometric measurements were standardized to a $1-\mathrm{cm}$ cell. 
Wine Production. After the 2004 harvest, equal lots $(4000 \mathrm{lb})$ of grapes from each cultivar and farming method were processed into wine at Paso Robles Wine Services Winery (Paso Robles, CA). The wines were produced using the winery's commercial method, with all cultivars and farming methods receiving comparable treatment.

Sensory evaluation. Sensory evaluation was performed on the wine from the 2004 vintage by Vinquiry Analytical Services (Windsor, CA) in 2005. Five highly trained, experienced wine judges evaluated the wines. All wines were served in clear, tulip-shaped $220-\mathrm{mL}$ wine glasses coded with three-digit random numbers. At least $\mathrm{l} \mathrm{h}$ before evaluation, a $50-\mathrm{mL}$ sample of the wine was poured into each glass, and the glasses were covered with a plastic petri dish. Sensory evaluation was conducted in a room illuminated with fluorescent lighting. All wines were served at $18^{\circ} \mathrm{C}$ on tables with white surfaces. The wines from each cultivar were presented to the panelists in random order. Panelists were isolated from one another by partitions.

Wines were evaluated by cultivar using the UC Davis 20-point system (Amerine and Singleton, 1977). Evaluation criteria included appearance (cloudy $=0$, clear $=1$, brilliant $=2$ ), color (distinctly off $=0$, slightly off $=1$, correct $=2$ ), aroma and bouquet (faint $=1$, slight $=2$, pronounced $=3$; subtracting 1 or 2 for off-odors and adding 1 for noticeable bouquet from aging), acetic acid ( obvious $=0$, slight $=1$, none $=2$ ), total acidity (distinctly low or high $=$ 0 , slightly low or high $=1$, normal $=$ 2 ), sweetness (too high or low $=0$, normal $=1)$, body (too high or low = 0 , normal $=1$ ), flavor (distinctly abnormal or deficient $=0$, slightly abnormal $=1$, normal $=2$ ), bitterness and astringency (distinctly high $=0$, slightly high $=1$, normal $=2$ ), and general quality (lacking $=0$, slight $=1$, impressive $=2$ ). Scores for all evaluation criteria were totaled, and the total ratings were classified as superior (17-20), standard (13-16), below standard (9-12), or unacceptable or spoiled (1-8).

Economic evaluation. In June 2006, M. Thomsen, University of Arkansas, Department of Agricultural Economics, and J. Morris worked with the French Camp Vineyards manager to gather data and develop budgets to estimate the economic impact of mechanizing balanced cropping operations for wine grapes grown on three types of trellises: VSP, 2 - $\mathrm{ft}$ lyre, and $3-\mathrm{ft}$ quad. Production operations evaluated were those described in the model operations for each trellis type presented by Noguera et al. (2005). Data for these estimates were obtained from records maintained by the vineyard manager as well as from actual operating costs during the study years. Production operations that were not mechanized were assumed to be the same for both farming systems and were not included in the cost estimates.

Statistical analysis. Because of limitations in experimental design associated with conducting this verification study in a commercial vineyard, data analysis for yield, berry weights, and grape quality parameters were conducted on averages of three harvest seasons. Sensory data were analyzed using panelists as replication. All data were subjected to analysis of variance with SAS (release 8.01 TS, Level 01M; SAS Institute, Cary, NC). Mean separations of wine composition and sensory data were accomplished using Tukey's multiple comparison test at $P<0.05$.

\section{Results and discussion}

As shown in Table 1 , in a high percentage of the cultivars, shoots per meter of cordon on machine-farmed plots were about double the number of shoots on the hand-pruned plots. Pruning weights were similar between hand and machine farming. In the 3 years represented here, no untoward weather events or natural disasters occurred that would limit the crop load on the hand-pruned vines. In regions where frost is not a major concern, it may be advantageous to reduce the crop to $110 \%$ by shoot thinning because the shoot-thinning operation can be accomplished more rapidly than fruit thinning. Also, there may be occasions in high-quality situations where additional shoot thinning would be necessary to maximize sunlight penetration into the fruit zone.

The results of the 2003-2005 seasons' yields are shown in Table 2 . These data indicate that actual yields were close to target yields required by the purchasing winery, but the accuracy of achieving the target yields was somewhat variable between cultivars and years. The vineyard manager indicated that in actual large-scale production, the machine-farmed vines may more closely reach target production levels than the hand-farmed vines because mechanized farming is more precise and consistent than hand farming. However, for this research study, workers were monitored vigilantly, resulting in more precise yields than are sometimes seen.

Table 1. Comparison of shoot density after pruning and pruning weight for Vitis vinifera grapes that were either machine or hand farmed at French Camp Vineyards, Santa Margarita, CA (2003-2005).

\begin{tabular}{|c|c|c|c|c|c|c|}
\hline \multirow[b]{2}{*}{ Cultivar } & \multirow[b]{2}{*}{ Farming method } & \multicolumn{3}{|c|}{$\begin{array}{l}\text { Shoot density } \\
\left(\text { shoots } \cdot \mathrm{m}^{-1}\right)^{\mathrm{z}}\end{array}$} & \multicolumn{2}{|c|}{$\begin{array}{l}\text { Pruning wt } \\
\left(\mathrm{kg} \cdot \mathrm{m}^{-1}\right)^{\mathrm{z}, \mathrm{y}}\end{array}$} \\
\hline & & 2003 & 2004 & 2005 & 2003 & 2004 \\
\hline \multirow[t]{2}{*}{ Chardonnay $^{x}$} & Hand & 10 & 13 & 16 & 0.52 & 0.33 \\
\hline & Machine & 18 & 32 & 25 & 0.45 & 0.33 \\
\hline \multirow[t]{2}{*}{ Sauvignon blanc ${ }^{\mathrm{x}}$} & Hand & 13 & 13 & 13 & 0.79 & 0.30 \\
\hline & Machine & 24 & 30 & 32 & 0.79 & 0.37 \\
\hline \multirow[t]{2}{*}{ Merlot $^{\mathrm{w}}$} & Hand & 13 & 13 & 13 & 0.45 & 0.52 \\
\hline & Machine & 17 & 30 & 28 & 0.36 & 0.49 \\
\hline \multirow[t]{2}{*}{ Sangiovese ${ }^{\mathrm{w}}$} & Hand & 13 & 13 & 11 & 0.57 & 0.58 \\
\hline & Machine & 18 & 24 & 26 & 0.39 & 0.39 \\
\hline \multirow[t]{2}{*}{ Syrah $^{x}$} & Hand & 13 & 13 & 13 & 0.67 & 0.48 \\
\hline & Machine & 27 & 25 & 28 & 0.64 & 0.45 \\
\hline \multirow[t]{2}{*}{ Zinfandel $^{w}$} & Hand & 10 & 13 & 13 & 0.61 & 0.82 \\
\hline & Machine & 20 & 31 & 23 & 0.43 & 0.74 \\
\hline
\end{tabular}

${ }^{\mathrm{z}} 1$ shoot $\cdot \mathrm{m}^{-1}=0.3048$ shoot $/ \mathrm{ft} ; 1 \mathrm{~kg} \cdot \mathrm{m}^{-1}=0.6720 \mathrm{lb} / \mathrm{ft}$.

yPruning weights were taken only during the first 2 years of this study.

${ }^{2} 2-\mathrm{ft}(0.6-\mathrm{m})$ lyre trellis.

"Vertical shoot-positioned trellis. 
Table 2. Comparison of target yields requested by winery with actual yields for Vitis vinifera grapes hand or machine farmed at French Camp Vineyards, Santa Margarita, CA (2003-2005).

\begin{tabular}{|c|c|c|c|c|c|c|c|c|c|c|}
\hline \multirow[b]{2}{*}{ Cultivar } & \multirow[b]{2}{*}{$\begin{array}{l}\text { Farming } \\
\text { method }\end{array}$} & \multicolumn{3}{|c|}{2003} & \multicolumn{3}{|c|}{2004} & \multicolumn{3}{|c|}{2005} \\
\hline & & $\begin{array}{c}\text { Target } \\
\text { yield } \\
\left(\mathrm{t} \cdot \mathrm{ha}^{-1}\right)^{\mathrm{z}}\end{array}$ & $\begin{array}{c}\text { Actual } \\
\text { yield } \\
\left(\mathrm{t} \cdot \mathrm{ha}^{-1}\right)\end{array}$ & $\begin{array}{c}\text { Difference } \\
\text { (target - } \\
\text { actual) })^{y}\end{array}$ & $\begin{array}{c}\text { Target } \\
\text { yield } \\
\left(\mathrm{t} \cdot \mathrm{ha}^{-1}\right)\end{array}$ & $\begin{array}{c}\text { Actual } \\
\text { yield } \\
\left(\mathbf{t} \cdot \mathbf{h a}^{-1}\right)\end{array}$ & $\begin{array}{c}\text { Difference } \\
\text { (target - } \\
\text { actual) }\end{array}$ & $\begin{array}{c}\text { Target } \\
\text { yield } \\
\left(\mathrm{t} \cdot \mathrm{ha}^{-1}\right)\end{array}$ & $\begin{array}{c}\text { Actual } \\
\text { yield } \\
\left(\mathrm{t} \cdot \mathrm{ha}^{-1}\right)\end{array}$ & 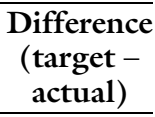 \\
\hline \multirow[t]{2}{*}{ Chardonnay $^{y}$} & Hand & 17.9 & 14.1 & -3.8 & 18 & 18.8 & +0.8 & 22.4 & 28.8 & +6.4 \\
\hline & Machine & 17.9 & 15.7 & -2.2 & 18 & 15.7 & -2.3 & 22.4 & 24.4 & +2 \\
\hline Sauvignon blanc ${ }^{\mathrm{y}}$ & Hand & 17.9 & 18.2 & +0.3 & 20 & 20.8 & +0.8 & 22.4 & 20.9 & -1.5 \\
\hline & Machine & 13.5 & 14.6 & +1.1 & 15.7 & 17.5 & +1.8 & 15.7 & 13.8 & -1.9 \\
\hline \multirow[t]{2}{*}{ Sangiovese ${ }^{\mathrm{x}}$} & Hand & 6.7 & 6.7 & -0 & 9 & 15.7 & +6.7 & 11.2 & 10.8 & -0.4 \\
\hline & Machine & 6.7 & 7.4 & +0.7 & 9 & 10 & +1 & 11.2 & 16.5 & +5.3 \\
\hline \multirow[t]{2}{*}{ Syrah $^{y}$} & Hand & 15.7 & 14.3 & -1.4 & 17 & 12.8 & -4.2 & 18 & 20.9 & +2.9 \\
\hline & Machine & 15.7 & 14.6 & -1.1 & 17 & 22 & +5 & 18 & 15.6 & -2.4 \\
\hline Zinfandel $^{x}$ & Hand & 15.7 & 16.1 & +0.4 & 13.5 & 8.7 & -4.8 & 13.5 & 17 & +3.5 \\
\hline
\end{tabular}

${ }^{\mathrm{z}} 1 \mathrm{t} \cdot \mathrm{ha}^{-1}=0.446 \mathrm{l}$ ton/acre.

y 2 -ft $(0.6-\mathrm{m})$ lyre trellis.

${ }^{\mathrm{x}}$ Vertical shoot-positioned trellis.

Table 3. Composition and berry weight for Vitis vinifera grapes hand or machine farmed at French Camp Vineyards, Santa Margarita, CA (2003-2005).

\begin{tabular}{llcccc}
\hline Cultivar & $\begin{array}{l}\text { Farming } \\
\text { method }\end{array}$ & $\begin{array}{c}\text { Berry } \\
\mathbf{w t}(\mathbf{g})^{\mathbf{z}}\end{array}$ & $\mathbf{p H}$ & $\begin{array}{c}\text { Soluble solids } \\
(\mathbf{\%})\end{array}$ & $\begin{array}{c}\text { Titratable acidity } \\
\left(\mathbf{g} \cdot \mathbf{L}^{-\mathbf{1}}\right)^{\mathbf{y}}\end{array}$ \\
\hline Chardonnay $^{\mathrm{x}}$ & Hand & 1.02 & 3.65 & 23.0 & 8.6 \\
& Machine & 1.03 & 3.56 & 23.1 & 8.4 \\
Sauvignon blanc $^{\mathrm{x}}$ & Hand & 1.09 & 3.71 & 22.7 & 6.0 \\
& Machine & 1.04 & 3.64 & 22.8 & 5.9 \\
Merlot $^{\mathrm{w}}$ & Hand & 0.92 & 3.53 & 24.3 & 7.8 \\
& Machine & 0.91 & 3.53 & 24.7 & 8.2 \\
Sangiovese $^{\mathrm{w}}$ & Hand & 1.22 & 3.68 & 25.1 & 6.8 \\
& Machine & 1.14 & 3.56 & 26.7 & 6.7 \\
Syrah $^{\mathrm{x}}$ & Hand & 0.93 & 3.68 & 25.4 & 8.0 \\
& Machine & 0.83 & 3.64 & 24.5 & 7.8 \\
Zinfandel $^{\mathrm{w}}$ & Hand & 1.27 & 3.49 & 24.6 & 8.4 \\
& Machine & 1.18 & 3.50 & 24.3 & 8.0 \\
$P$ & & $\mathrm{NS}$ & $\mathrm{NS}$ & $\mathrm{NS}$ & $\mathrm{NS}$ \\
\hline
\end{tabular}

${ }^{\mathrm{z}} 1 \mathrm{~g}=0.0353 \mathrm{oz}$.

Titratable acidity as tartaric acid; $1 \mathrm{~g} \cdot \mathrm{L}^{-1}=1000 \mathrm{ppm}$.

${ }^{2} 2$ - $\mathrm{ft}(0.6-\mathrm{m})$ lyre trellis.

"Vertical shoot-positioned trellis.

${ }^{\mathrm{N} S}=$ Means (average of 3 years) within a column and cultivar are not significantly different by Tukey test $(P \leq 0.05)$

Average berry sizes from the two farming treatments are shown in Table 3. For all cultivars except Chardonnay, the berries were slightly smaller with machine farming than with hand farming. However, the differences were not significant in this study. A similar pattern was seen by Petrie et al. (2003) when comparing hand and machine thinning. The differences in berry size were not significant in their study, either. Wample et al. (1996) reported a slight reduction in berry size with mechanized farming of
Concord grapes during a 10-year study conducted in Washington state. They hypothesized this could be a positive outcome because smaller grapes have a higher skin-to-berry volume ratio that can result in improved color of juice and wine products.

Farming method did not result in any significant differences in fruit composition for any of the cultivars (Table 3). Sensory evaluation found no differences between wines from hand- or machine-farmed grapes, in nine of the 10 attributes shown in
Table 4 . The one exception was that wine made from the machine-farmed Sangiovese grapes was identified as more sweet (too high or low $=0$, normal $=1$ ) than wine from the handfarmed fruit. However, the residual glucose + fructose levels of the machine-farmed and hand-farmed Sangiovese wine were $0.43 \%$ and $0.12 \%$, respectively, which is below the $2 \%$ limit for a table wine (Table 5 ).

Although statistical differences were found in the wine, there were no commercially practical differences. The $\mathrm{pH}(3.35-3.77)$ and titratable acidity $\left(6.44-7.31 \mathrm{~g} \cdot \mathrm{L}^{-1}\right)$ levels of the wines were all within an acceptable range. The red grape cultivars produced wine with total red pigment values ranging from 4.52 absorbance units (a.u.) for Zinfandel to 9.32 a.u. for Syrah. Total phenolics of the red wines were $34-43$ a.u. The residual glucose + fructose levels of the wines were $<0.5 \%$. Ethanol levels of the wines were $12.6 \%$ to $15.3 \%$.

A comparison of the costs of activities necessary to achieve balanced cropping revealed that for hand farming, costs were mainly those associated with maintaining a large enough labor pool to ensure that all operations were performed in a timely fashion. Factors influencing the costs of machine farming included the costs of purchasing or leasing equipment, equipment maintenance and repair, labor to operate and maintain the 


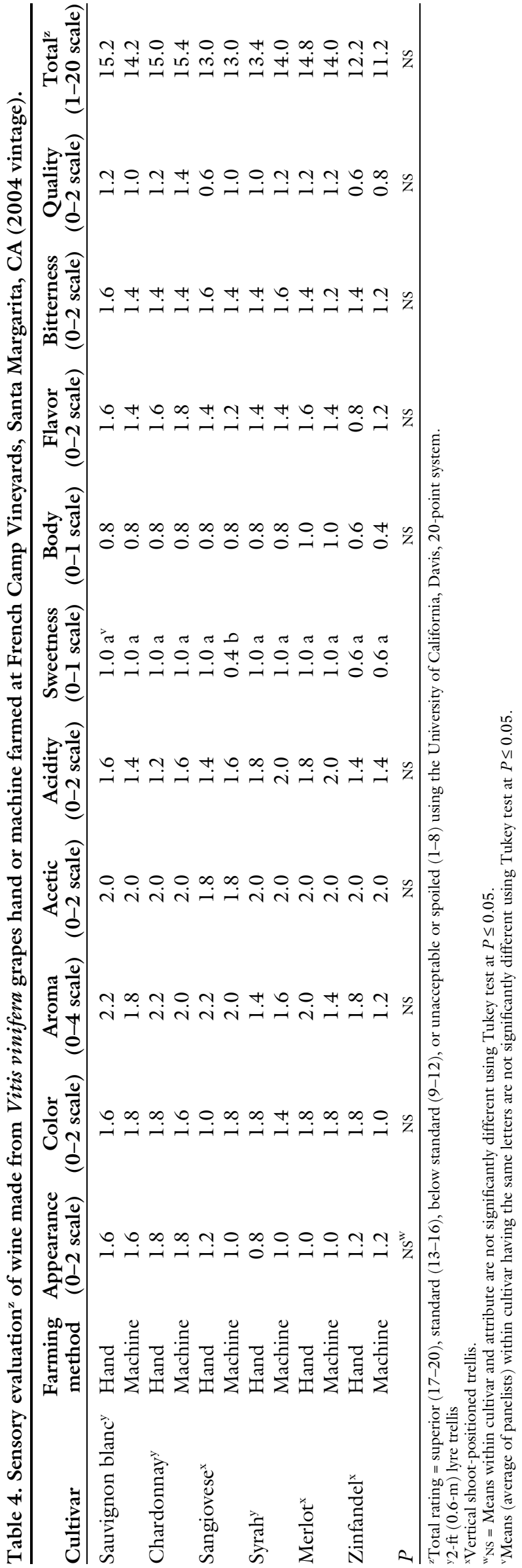

equipment, and fuel and lubrication costs. Also included in cost calculations was the fact that machine farming increases trellis maintenance requirements by $1 \%$ for lyre and VSP systems.

The costs of mechanically pruning, shoot thinning, and fruit thinning reflected the costs of owning and operating the Korvan ${ }^{\mathrm{TM}}$ equipment in the M-O System. In the region being studied, shoot thinning was necessary in most years while fruit thinning was necessary in about $\mathrm{l}$ of 2 years. For this reason, the budgets reflected the full costs of a shootthinning operation and one-half of the costs of a fruit-thinning operation. The mechanized operations greatly reduced but did not entirely eliminate the need for hand labor. Small ground crews were needed to follow-up, measure, and provide information to machine operators. Hand-farming costs used in the calculations reflected typical practices in the region. Hand pruning was charged as a piece rate and followed a prepruning operation. Hand labor for shoot and fruit thinning were charged hourly. While not directly evident from the data presented, hand-labor costs under mechanized farming were only $8 \%$ to $15 \%$ of those under traditional methods.

The economic analysis of balanced cropping operations showed that costs saved through mechanization were economically significant (Table 6). For the operations studied, machine farming resulted in a $45 \%$ savings over hand farming for grapes produced on the lyre trellis, $49 \%$ savings on the VSP system, and $62 \%$ savings on the quad trellis. The largest cost savings were realized from the shoot-thinning and fruit-thinning operations. Differences in cost savings for these operations among the trellising systems largely reflected differences in vine spacing that impacted field speeds. Piece rates for pruning operations varied by trellising system.

The vineyard manager noted that mechanization provides other benefits in addition to the economic advantages shown here. First, mechanization helps stabilize grape yield through the concept of balanced cropping. Because the grower was able to make final adjustment on crop size late in the growing season, growers were afforded an opportunity 
Table 5. Evaluation of wine made from Vitis vinifera grapes hand or machine farmed at French Camp Vineyards, Santa Margarita, CA (2004 vintage).

\begin{tabular}{|c|c|c|c|c|c|c|}
\hline Cultivar & $\begin{array}{l}\text { Farming } \\
\text { method }\end{array}$ & $\mathrm{pH}$ & $\begin{array}{l}\text { Titratable } \\
\text { acidity } \\
\left(\mathrm{g} \cdot \mathrm{L}^{-1}\right)^{\mathrm{z}}\end{array}$ & $\begin{array}{l}\text { Total red } \\
\text { pigments } \\
{\text { (a.u. })^{y}}^{\text {(agment }}\end{array}$ & $\begin{array}{c}\text { Total } \\
\text { phenolics } \\
\text { (a.u.) }\end{array}$ & $\begin{array}{c}\text { Residual } \\
\text { glucose }+ \\
\text { fructose } \\
(\%)\end{array}$ \\
\hline \multirow[t]{2}{*}{ Sauvignon blanc ${ }^{x}$} & Hand & $3.39 \mathrm{a}^{\mathrm{v}}$ & $6.56 \mathrm{a}$ & $一^{\mathrm{u}}$ & - & $0.11 \mathrm{a}$ \\
\hline & Machine & $3.35 \mathrm{~b}$ & $6.53 \mathrm{a}$ & - & - & $0.09 \mathrm{~b}$ \\
\hline \multirow[t]{2}{*}{ Chardonnay $^{\mathrm{x}}$} & Hand & $3.43 \mathrm{a}$ & $6.57 \mathrm{~b}$ & - & - & $0.23 \mathrm{a}$ \\
\hline & Machine & $3.43 \mathrm{a}$ & $7.08 \mathrm{a}$ & - & - & $0.18 \mathrm{~b}$ \\
\hline \multirow[t]{2}{*}{ Sangiovese ${ }^{\mathrm{w}}$} & Hand & $3.60 \mathrm{~b}$ & $6.87 \mathrm{~b}$ & $5.81 \mathrm{~b}$ & $36.8 \mathrm{~b}$ & $0.12 \mathrm{~b}$ \\
\hline & Machine & $3.77 \mathrm{a}$ & $7.17 \mathrm{a}$ & $7.14 \mathrm{a}$ & $42.6 \mathrm{a}$ & $0.43 \mathrm{a}$ \\
\hline \multirow[t]{2}{*}{ Syrah $^{\mathrm{x}}$} & Hand & $3.67 \mathrm{a}$ & $6.73 \mathrm{a}$ & $9.32 \mathrm{a}$ & $36.3 \mathrm{a}$ & $0.10 \mathrm{a}$ \\
\hline & Machine & $3.66 \mathrm{a}$ & $7.31 \mathrm{a}$ & $9.32 \mathrm{a}$ & $35.8 \mathrm{a}$ & $0.08 \mathrm{~b}$ \\
\hline \multirow[t]{2}{*}{ Merlot $^{\mathrm{w}}$} & Hand & $3.62 \mathrm{a}$ & $6.44 \mathrm{a}$ & $8.13 \mathrm{a}$ & $34.3 \mathrm{a}$ & $0.06 \mathrm{a}$ \\
\hline & Machine & $3.53 \mathrm{~b}$ & $6.77 \mathrm{a}$ & $7.53 \mathrm{~b}$ & $33.8 \mathrm{a}$ & $0.06 \mathrm{a}$ \\
\hline \multirow[t]{2}{*}{ Zinfandel $^{w}$} & Hand & $3.60 \mathrm{a}$ & $6.85 \mathrm{a}$ & $4.62 \mathrm{a}$ & $36.4 \mathrm{a}$ & $0.11 \mathrm{a}$ \\
\hline & Machine & $3.54 \mathrm{~b}$ & $6.89 \mathrm{a}$ & $4.52 \mathrm{~b}$ & $36.5 \mathrm{a}$ & $0.10 \mathrm{a}$ \\
\hline
\end{tabular}

${ }^{2}$ Titratable acidity as tartaric acid $1 \mathrm{~g} \cdot \mathrm{L}^{-1}=1000 \mathrm{ppm}$.

yAbsorbance units.

${ }^{2} \mathrm{ft}(0.6 \mathrm{~m})$ Lyre trellis.

"Vertical shoot-positioned trellis.

"Means within cultivar and component having the same letters are not significantly different using Tukey test at $P \leq 0.05$.

"Data not obtained.

Table 6. Comparison of total costs for pruning, shoot thinning, and fruit thinning by hand or machine of Vitis vinifera grapes grown on three trellis systems at French Camp Vineyards, Santa Margarita, CA (2005 season).

\begin{tabular}{|c|c|c|c|}
\hline & \multicolumn{3}{|c|}{ Total cost $(\$ / \text { acre })^{z}$} \\
\hline & $V_{S P}$ & Lyre $^{x}$ & Quad $^{\text {w }}$ \\
\hline \multicolumn{4}{|l|}{ Machine-farmed } \\
\hline Prune & 119.84 & 239.67 & 157.28 \\
\hline Follow-up & 67.35 & 72.08 & 47.36 \\
\hline Shoot thin & 78.03 & 156.07 & 117.05 \\
\hline Fruit thin & 78.46 & 78.46 & 58.84 \\
\hline Total & 343.68 & 546.28 & 380.53 \\
\hline \multicolumn{4}{|l|}{ Hand-farmed } \\
\hline Pre-prune & 26.93 & 53.86 & 37.87 \\
\hline Prune & 251.04 & 386.92 & 317.76 \\
\hline Shoot thin & 232.00 & 463.99 & 463.99 \\
\hline Fruit thin & 109.16 & 175.87 & 175.87 \\
\hline Total & 619.13 & 1080.64 & 995.49 \\
\hline Difference (Hand - machine) & 275.45 & 534.36 & 614.96 \\
\hline
\end{tabular}

${ }^{\mathrm{z}} \$ 1.00 \cdot \mathrm{ha}^{-1}=\$ 0.4047 /$ acre.

Vertical shoot-positioned trellis.

${ }^{\mathrm{x}} 2 \mathrm{-ft}(0.6-\mathrm{m})$ lyre trellis.

w $3-\mathrm{ft}(0.9-\mathrm{m})$ quadrilateral trellis.

to compensate for crop losses due to frost injury, poor growing conditions, or poor fruit set. Second, by eliminating reliance on hand labor, the vineyard manager was able to retain fewer but better-trained workers. Over time, this promises to reduce overhead for human resources-related expenses and to lower costs associated with managing liability.

\section{Conclusion}

Results of research for the 20032005 seasons at the French Camp
Vineyards, CA, have shown that yield and quality characteristics of machine-farmed grapes were not different from those of hand-farmed grapes for the cultivars in this study (Chardonnay, Sauvignon blanc, Merlot, Syrah, Zinfandel, and Sangiovese). Almost no sensory differences between wines from the two farming systems in each cultivar were identified.

In 2006, cost estimates were derived for each of the vineyard activities necessary to achieve balanced cropping. Machine farming of the three operations resulted in a $45 \%$ savings over hand farming for grapes produced on the lyre trellis, $49 \%$ savings on the VSP trellis, and 62\% savings on the quad trellis.

Commercial verification studies of mechanization of vineyard activities to achieve balanced cropping have shown that grapes and wine were equivalent to those obtained using hand labor for these operations. With the added benefit of cost savings, it can be concluded that implementation of mechanization systems, such as the M-O System, will assist growers in remaining competitive in world markets.

\section{Literature cited}

Amerine, M.A. and V.L. Singleton. 1977. Wine-An introduction. University of California Press, Berkeley, CA.

Fisher, K.H., B. Piott, and T. Tancock. 1997. Estimating Concord crops for machine thinning accuracy. Proc. 4th Intl. Symp. Cool Climate Viticult. Enol. 4: 28-32.

Iland, P., N. Bruer, G. Edwards, S. Weeks, and E. Willkes. 2004. Chemical analysis of grapes and wine: techniques and concepts. Patrick Iland Wine Promotions, Campbelltown, South Australia.

May, P. 1995. A quarter century of mechanical grape harvesting in Australia. Wine Ind. J. 10(1):41-45.

Morris, J.R. 1979. Mechanical combing and pruning of 'Concord' grapes. Proc. Annu. Mtg. Arkansas State Hort. Soc. 100:76-83.

Morris, J.R. 1985. Approaches to more efficient vineyard management. HortScience 20:1009-1013.

Morris, J.R. 1986. Mechanizing 'Concord' vineyards for greater profits. Proc. Annu. Mtg. Arkansas State Hort. Soc. 107:146-153.

Morris, J.R. 2000. Past, present, and future of vineyard mechanization. Amer. J. Enol. Viticult. 51(5):155-163.

Morris, J.R. 2004. Vineyard mechanization-a total systems approach. Wines Vines 85(4):20-24.

Morris, J. 2006. Development and incorporation of mechanisation into intensely managed grape vineyards. Keynote Paper WG6. In Paper and Abstract Book, 6th Intl. Cool Climate Symp. Viticult. and Enol. Christchurch, New Zealand. p. 6883. 
Morris, J.R. and D.L. Cawthon. 1979. Response of 'Concord' grapes to training systems and pruning severity. Ark. Farm Res. 28(5):12.

Morris, J.R. and D.L. Cawthon. 1980a. Mechanical pruning of cordon-trained 'Concord' grapevines. Ark. Farm Res. 29(2):12.

Morris, J.R. and D.L. Cawthon. 1980b. Mechanical trimming and node adjustment of cordon-trained 'Concord' grapevines. J. Amer. Soc. Hort. Sci. 105:310313.

Morris, J.R. and D.L. Cawthon. 1980c. Yield and quality response of 'Concord' grapes to training systems and pruning severity in Arkansas. J. Amer. Soc. Hort. Sci. 105:307-310.

Morris, J.R. and D.L. Cawthon. 1981a. Mechanical pruning of grapes. Proc. Annu. Mtg. Ark. State Hort. Soc. 102:141-146.

Morris, J.R. and D.L. Cawthon. 1981b. Yield and quality response of 'Concord' grapes (Vitis labrusca L.) to mechanized vine pruning. Amer. J. Enol. Viticult. 32:280-282.

Morris, J.R. and T.L. Oldridge. 2002. University of Arkansas. Vineyard apparatus, system, and method for vineyard mechanization. U.S. Patent 6,374,538. U.S. Patent and Trademark Office, Washington, D.C.
Morris, J.R., C.A. Sims, J.E. Bourque, and J.L. Oakes. 1984a. Influence of training system, pruning severity and spur length on yield and quality of six French-American hybrid grape cultivars. Amer. J. Enol. Viticult. 35:23-27.

Morris, J.R., D.L. Cawthon, and C.A. Sims. 1984b. Long-term effects of pruning severity, nodes per bearing unit, training system and shoot positioning on yield and quality of 'Concord' grapes. J. Amer. Soc. Hort. Sci. 109:676-683.

Morris, J.R., D.L. Cawthon, and J.W. Fleming. 1979. Effects of temperatures and potassium meta-bisulfite on quality and postharvest behavior of mechanically harvested 'Concord' grapes in Arkansas. J. Amer. Soc. Hort. Sci. 104:166-169.

Noguera, E., J. Morris, K. Striegler, and M. Thomsen. 2005. Production budgets for Arkansas wine and juice grapes. Ark. Agr. Expt. Sta. Res. Rpt. No. 976.

Petrie, P.R., P.R. Clingeleffer, and M.P. Krstic. 2003. Mechanical thinning to stabilise yield and improve grape maturity and colour. Aust. N.Z. Grapegrower Winemaker 473a:118-120.

Pool, R.M., R. Dunst, and A. Fendinger. 1996. Regulating crop and quality of machine and minimally pruned Concord grapevines, p. 51-56. Proc. 1st Vincent E. Petrucci Viticult. Symp. California State Univ., Fresno, CA.
Shaulis, N.J., E.S. Shepardson, and J.C. Moyer. 1960. Grape harvesting research at Cornell. Proc. 105th NY State Hort. Soc., 105:250-254. Rochester, NY. State Hort. Soc. 105:250-254.

Shepardson, E.S., N.J. Shaulis, and J.C. Moyer. 1969. Mechanical harvesting of grape varieties grown in New York State, p. 571-609. In: B.F. Cargill and G.E. Rossmiller (eds.). Fruit and vegetable harvest mechanization, technological implications. Rural Manpower Center, Michigan Sate University, East Lansing.

Walker, T., J. Morris, R. Threlfall, and G. Main. 2003. Analysis of wine components in Cynthiana and Syrah wines. J. Agr. Food Chem. 51:1543-1547.

Wample, R.L., L. Mills, and A. Wichers. 1996. Mechanical pruning - the influence on yield components, nutrition, and fruit quality factors in Concord grape production in Washington State after ten years, $\mathrm{p}$. 35-56. Washington State Grape Soc. Proc Nov. 20-26, 1996. Grandview, WA.

Winkler, A.J., L.H. Lamouria, and G.H. Abernathy. 1957. Mechanical grape harvest problems and progress. Amer. J. Enol. Viticult. 8(4):182-187.

Zoecklein, B.W., K.C. Fugelsang, B.H. Gump, and F.S. Nury. 1995. Wine analysis and production. Chapman and Hall, New York. 